\title{
Decoupling between bacteria and the surf-zone diatom Asterionellopsis glacialis at Cassino Beach, Brazil
}

\author{
Paulo C. Abreu ${ }^{1, *}$, Leonardo R. Rörig ${ }^{2}$, Virginia Garcia ${ }^{1}$, Clarisse Odebrecht ${ }^{1}$, \\ Bopaiah Biddanda $^{3}$
}

\author{
${ }^{1}$ Departmento de Oceanografia, Fundação Universidade Federal do Rio Grande (FURG), Caixa Postal 474, \\ 96201-900 Rio Grande, RS, Brazil \\ ${ }^{2}$ Departmento de Oceanografia - CTTMAR, Universidade do Vale do Itajaí (UNIVALI), 88302-202 Itajaí, SC, Brazil \\ ${ }^{3}$ Annis Water Resources Institute and Lake Michigan Center, Grand Valley State University, 740 West Shoreline Drive, \\ Muskegon, Michigan 49441, USA
}

\begin{abstract}
The surf-zone diatom Asterionellopsis glacialis (Castracane) Round attains extremely

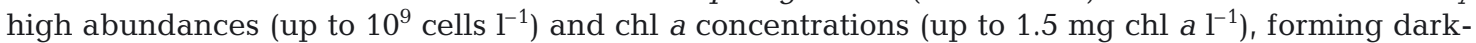
brown patches in Cassino Beach, southern Brazil. Several lines of evidence from this study indicate a decoupling between $A$. glacialis and heterotrophic bacteria. For instance, despite the high abundance of diatoms, associated high levels of chl a and rates of dissolved organic carbon (DOC) production by A. glacialis, bacterial abundance at Cassino Beach was extremely low $\left(0.03\right.$ to $0.7 \times 10^{6}$ cells $\mathrm{ml}^{-1}$ ) compared to the nearby estuarine waters, adjacent coastal waters and those from the literature. No statistical differences were found between bacterial abundance in- and outside the diatom patches, suggesting that direct association with A. glacialis did not stimulate bacterial growth. Moreover, field and laboratory experiments demonstrated that bacteria take 1 to $4 \mathrm{~d}$ to begin growing following the input of $A$. glacialis cell-free filtrate. Five possible reasons for this decoupling, i.e. (1) viral infection, (2) bacterial grazing, (3) DOC quality, (4) nutrient competition and (5) antibiotic production, are discussed. Because of the decoupling between the surf-zone diatom and heterotrophic bacteria in this high-energy surf-zone ecosystem, a large fraction of $A$. glacialis primary production is not contemporaneously channeled through the microbial food web. Consequently, much of the surf-zone diatom production may fuel metazoan secondary production in the adjacent nearshore and coastal environment.
\end{abstract}

KEY WORDS: Heterotrophic bacteria $\cdot$ Surf-zone diatom $\cdot$ Decoupling $\cdot$ Nearshore carbon flow

\section{INTRODUCTION}

Exposed sand beaches can be classified into 6 categories according to sediment characteristics and wave energy, varying from reflective, with coarse sediment and almost no surf-zone, to dissipative shores, which have fine sediment and a large surf-zone (Short \& Wright 1983). Another common characteristic of dissipative beaches is the presence of surf-zone diatoms. Around the world, only 6 diatom species (Aulacodiscus kitonii Arnott, A. petersi Ehrenberg, Anaulus australis Drebes et Schulz, Asterionellopsis glacialis [Castracane] Round, Asterionella socialis Lewin et Norris and Attheya armatus [West] Crawford) inhabit this ecosystem and may reach extremely high biomass (>1 mg chl a $\mathrm{l}^{-1}$ ) and primary production rates (500 to $2000 \mathrm{~g}$ $\mathrm{C} \mathrm{m}^{-3} \mathrm{yr}^{-1}$ ), supplying most of the organic matter demanded by the zooplankton, benthos and nekton present in these nearshore environments (Brown \& McLachlan 1990). Surf-zone diatom patch-formation 
was previously considered to be a blooming phenomenon, though it is now recognized that a high concentration of surf-zone diatoms results from shoreward movement of re-suspended cells (Talbot et al. 1990).

Studies carried out along the South African coast, where the surf-zone diatom Anaulus australis is the main primary producer (Brown \& McLachlan 1990), indicate that dissipative beaches are self-sustained ecosystems. Although a significant part (up to $25 \%$ ) of the primary production in these beaches is directly consumed by zooplankton and benthic filter-feeders, some studies pointed out the possibility that most of the carbon fixed by the surf-zone diatom is in the dissolved form, and flows through the microbial food web (McLachlan \& Bate 1985, Heymans \& McLachlan 1996).

Cassino Beach in southern Brazil $\left(32^{\circ} 13^{\prime} \mathrm{S}\right.$, $52^{\circ} 15^{\prime} \mathrm{W}$ ) shows intermediate to dissipative features throughout the year. Water temperature oscillates between 10 and $26^{\circ} \mathrm{C}$, and salinity varies from 17 to 35 . Nitrate + nitrite $(0.2$ to $9.7 \mu \mathrm{M})$, phosphate $(0.1$ to $3.6 \mu \mathrm{M}$ ) and silicate (3.5 to $66.1 \mu \mathrm{M}$ ) are normally present at low concentrations, except following major rainfall events, when enhanced freshwater outflow from the Patos Lagoon enriches the coastal region (Odebrecht et al. 1995, Rörig \& Gacia 2003). The surf-zone diatom Asterionellopsis glacialis frequently reaches a very high abundance in the water column $\left(10^{8}\right.$ to $10^{9}$ cells $\mathrm{l}^{-1}$ ), generating chl a values and primary production rates as high as $1647 \mu \mathrm{g} \mathrm{l}^{-1}$ and $6.0 \mathrm{mg} \mathrm{C} \mathrm{l}^{-1} \mathrm{~h}^{-1}$, respectively (Odebrecht et al. 1995, Reynaldi 2000, Rörig \& Garcia 2003). A high concentration of $A$. glacialis at Cassino Beach is associated with the meteorological regime. The passage of atmospheric fronts from the Antarctic over southern Brazil results in onshore winds that generate high wave energy (Odebrecht et al. 1995). The action of the waves removes cells from the beach sediment, while the shoreward wind concentrates them in the surf-zone, forming brown patches of algae (Odebrecht et al. 1995, Rörig \& Garcia 2003). A. glacialis provides up to $70 \%$ of the particulate organic carbon to the shore and represents the most important food item for the highly productive benthic and nektonic fauna of Cassino Beach and the nearshore environment (Garcia \& Gianuca 1997).

Total (particulate + dissolved) primary production during Asterionellopsis glacialis patch formation at Cassino Beach varies between 0.8 and $6.4 \mathrm{mg} \mathrm{C} \mathrm{l}^{-1} \mathrm{~h}^{-1}$, and as much as $68 \%$ of this is in the dissolved form (Reynaldi 2000). Such high production rates of particulate and dissolved organic matter (DOM) should favor the development of large bacterial biomass. However, during a year-long study carried out at this beach, we repeatedly observed a drastic reduction of bacterial abundance soon after the appearance of A. glacialis patches. On average, the abundance of bacteria at Cassino Beach was an order of magnitude lower than the nearby Patos Lagoon estuarine water (Abreu et al. 1992) and less than that found in the adjacent coastal region (Abreu 1997). Bacterial abundance at Cassino Beach is also much lower than that reported for limnetic and marine waters at comparable chl a levels (Cole et al. 1988, Biddanda et al. 2001). These observations indicate a strong decoupling between diatom production and bacterial growth. Moreover, A. glacialis is known to produce an antibiotic with an antimitotic property (Aubert et al. 1970). These facts led us to test the hypothesis of whether the surf-zone diatom inhibits bacterial growth in this ecosystem. Therefore, we have examined the dynamics of the surf-zone diatom A. glacialis and heterotrophic bacterioplankton in the field, as well as in controlled laboratory experiments.

\section{MATERIALS AND METHODS}

This study was conducted in 3 phases. In the first phase (field monitoring), water was collected at about weekly intervals at a fixed station at Cassino Beach, southern Brazil (Fig. 1), between June 1992 and

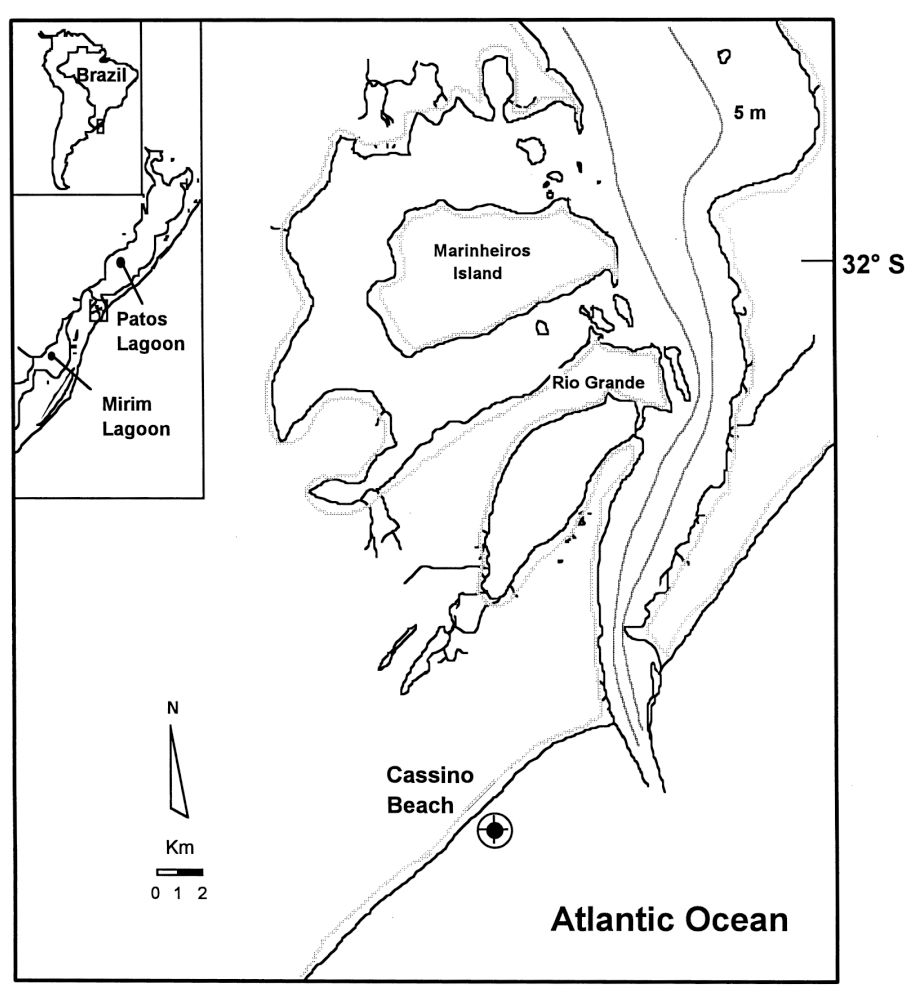

$52^{\circ} \mathrm{W}$

Fig. 1. Cassino beach, southern Brazil (32 $\left.13^{\prime} \mathrm{S}, 52^{\circ} 15^{\prime} \mathrm{W}\right)$. Encircled cross marks sampling station 
August 1993. Various abiotic factors (temperature, salinity and dissolved inorganic nutrients), as well as chl a concentration and Asterionellopsis glacialis abundance, were measured during this period (Rörig 1997). During this phase, A. glacialis was observed in high concentration 11 times, when water was sampled inside and outside (at least $10 \mathrm{~m}$ from the edge) the diatom patches. Daily samples were carried out after highest abundance of $A$. glacialis between 3 and 9 September 1993 and from 12 to 16 February 1996.

For Asterionellopsis glacialis and bacterial counts, small water volumes (100 to $200 \mathrm{ml}$ ) were fixed with neutral Lugol solution (Throndsen 1978) and stored in amber glass bottles. In the laboratory, bacterial abundance, differentiated in free and attached forms, was quantified using epifluorescence microscopy. Before filtration, samples were decolorized with few drops of a $3 \% \mathrm{w} / \mathrm{v}$ sodium thiosulphate solution (Nishino 1986). A $1 \mathrm{ml}$ sub-sample (duplicate) was concentrated onto black polycarbonate membrane filter (Nuclepore; $0.2 \mu \mathrm{m}$ pore size), and stained with $0.1 \%$ w/v Acridine Orange (Hobbie et al. 1977). Microorganisms were enumerated in 30 fields and chosen at random, using an epifluorescence microscope (Zeiss) under blue light excitation. The number of $A$. glacialis cells was also determined in the same samples. Cells were counted on the bottom of settling chambers using an inverted Nikon microscope, equipped with phase contrast, at $200 \times$ or $400 \times$ final magnification (Utermöhl 1958).

Water temperature $\left( \pm 0.1^{\circ} \mathrm{C}\right)$ and salinity $( \pm 0.5)$ were surveyed in situ using a Yellowspring thermosalinometer (Model $33 \mathrm{SCT}$ ). Chl a was measured after concentrating 50 to $100 \mathrm{ml}$ aliquots onto Whatman $\mathrm{GF} / \mathrm{F}$ glass fiber filters. This pigment was extracted in the dark at $-12{ }^{\circ} \mathrm{C}$ using $90 \% \mathrm{v} / \mathrm{v}$ acetone, and its concentration determined fluorometrically, using a calibrated Turner 111 fluorometer (Strickland \& Parsons 1972). Ammonium, nitrate + nitrite and phosphate concentrations were determined according to Strickland \& Parsons (1972). Chl a and dissolved inorganic nutrients were measured at least in duplicate. The parametric $t$-test was employed to determine statistical differences between samples inside and outside the diatom patches ( $\mathrm{p}<0.05)$ (Sokal \& Rohlf 1969).

In the second phase of the study (seawater growth experiments), we carried out laboratory experiments with water from Cassino Beach. After the accumulation of Asterionellopsis glacialis at Cassino Beach (maximum of $3.66 \times 10^{8}$ cells $\mathrm{l}^{-1}$ ) on 1 July 1997, surface water was sampled every $3 \mathrm{~d}$ for $3 \mathrm{wk}$. At $t=0$ (1 July; maximum abundance) and $t=14$ (15 July; low abundance), beach water was filtered through a Whatman GF/F fiber filter (0.75 $\mu \mathrm{m}$ pore size) and Nuclepore polycarbonate membrane filter $(0.2 \mu \mathrm{m}$ pore size). A total of $100 \mathrm{ml}$ filtered water microcosms (duplicate) were inoculated with unfiltered beach water $(10 \% \mathrm{v} / \mathrm{v})$ collected on the same day. The increase in bacterial abundance was followed daily for $1 \mathrm{wk}$. Such seawater growth experiments give an idea of the potential growth rate of bacteria under reduced grazing pressure (Ammerman et al. 1984)

In the third phase of the study, culture growth experiments were conducted with non-axenic batch cultures of Asterionellopsis glacialis. A. glacialis cells were isolated from Cassino Beach waters and grown in F2 medium (Guillard \& Ryther 1962) under $100 \mu \mathrm{E} \mathrm{m} \mathrm{m}^{-2}$ light condition in a 12:12 h light:dark cycle. Cultures were filtered (Whatman GF/F and Nuclepore $0.2 \mu \mathrm{m}$ ) after 7 (log phase) and $14 \mathrm{~d}$ (death phase), and the filtrate inoculated with unfiltered beach water $10 \%$ $\mathrm{v} / \mathrm{v}$ ) collected during a non-bloom period. Bacteria and A. glacialis abundance in the culture growth experiments (Ammerman et al. 1984) were determined as described above.

\section{RESULTS}

During the year-long study, water temperature varied between 10 and $26^{\circ} \mathrm{C}$, with minimum values during austral winter (June, July and August) and maximum during spring-summer. Salinity (17 to 35 ) followed a similar trend, mostly controlled by the amount of rain in the Patos Lagoon drainage basin. Ammonium concentration varied between non detectable values and $2.7 \mu \mathrm{M}$; nitrite + nitrate varied from 0.2 to $9.7 \mu \mathrm{M}$, while phosphate varied between 0.1 and $3.6 \mu \mathrm{M}$. Chl a ranged between 0.95 and $352.2 \mu \mathrm{g}^{-1}$ (Fig. 2). Highest chl a values $\left(\sim 300 \mu \mathrm{g} \mathrm{l}^{-1}\right)$ resulted from the accumulation of Asterionellopsis glacialis at the beach (maximum of $1.3 \times 10^{8}$ cells $1^{-1}$ ). During the year, bacterial abundance ranged from $0.3 \times 10^{5}$ to $0.7 \times 10^{6}$ cells ml $^{-1}$, with highest values occurring during austral summer (Fig. 2). Bacterial abundance for samples collected inand outside the A. glacialis patches showed no statistical differences (Table 1). However, the abundance of bacteria in samples collected at daily intervals increased, especially in the case of the attached bacteria, 4 to $5 \mathrm{~d}$ after $A$. glacialis reached its highest

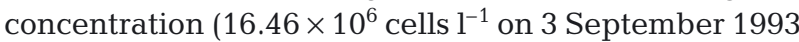
and $2.18 \times 10^{8}$ cells $1^{-1}$ on 12 February 1996) (Fig. 3A,B).

In July 1997, bacterial abundance at Cassino Beach did not show any significant increase in the first $3 \mathrm{~d}$ after the decrease in number of Asterionellopsis glacialis. However, after this initial period, bacterial abundance increased steadily to a maximum of $1.9 \times$ $10^{6}$ cells ml ${ }^{-1}$ (Fig. 4A). In the laboratory experiments with Cassino Beach filtered water collected during $A$. 


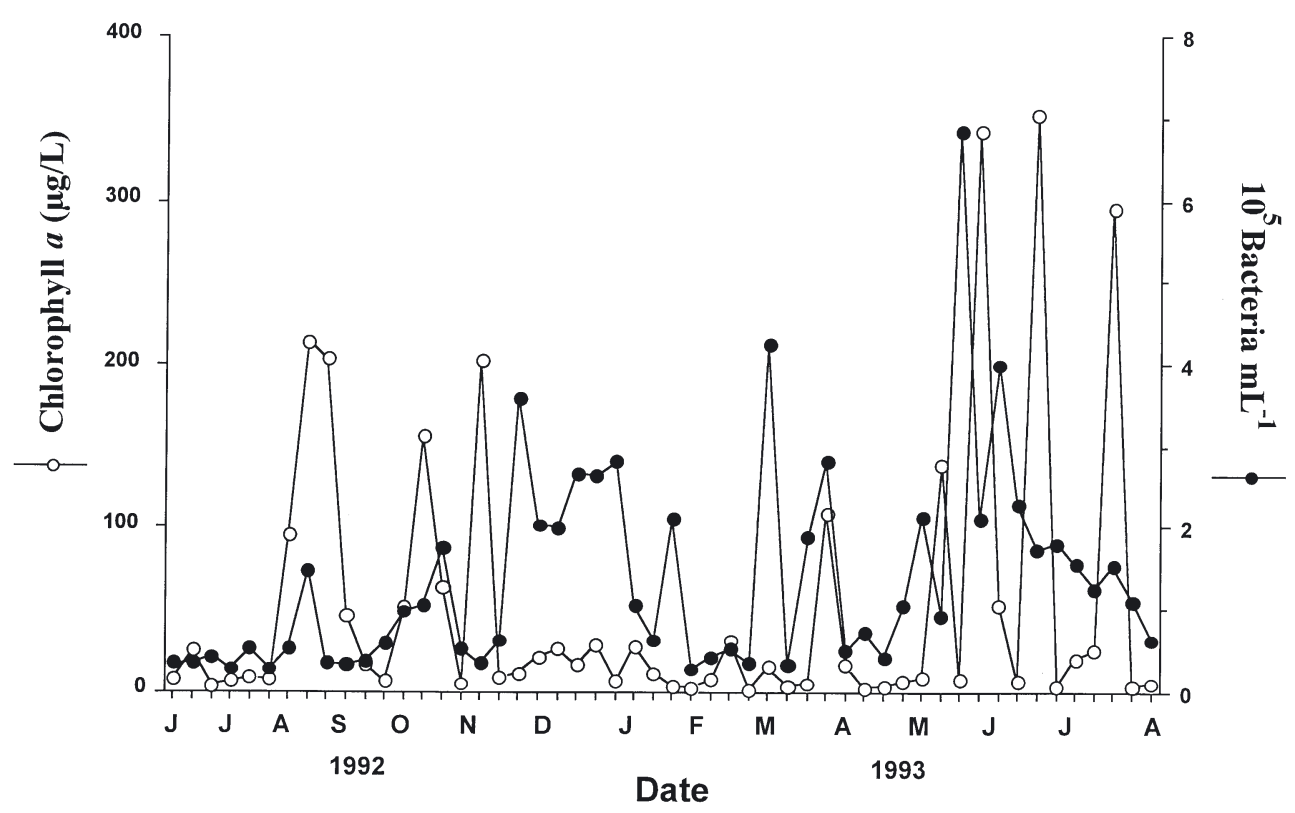

Fig. 2. Chl a $\left(\mathrm{g} \mathrm{g} \mathrm{l}^{-1}\right)$ and heterotrophic bacterial abundance $\left(10^{5}\right.$ cells ml $\left.{ }^{-1}\right)$ at Cassino Beach between June 1992 and August 1993

glacialis maximum abundance (Day 1, Fig. 4A), it was shown that the bacterial lag-phase extended to $4 \mathrm{~d}$ (Fig. 4B). On the other hand, in the experiment with filtered water collected when A. glacialis was of a low abundance following the collapse of the bloom (Day 14, Fig. 4A), the initial lag in bacterial growth prevailed only for $1 \mathrm{~d}$ (Fig. 4C). During both experiments there was no record of flagellates or ciliates.

In Asterionellopsis glacialis batch cultures, bacterial abundance increased steadily for $2 \mathrm{wk}$. However, bacterial growth rate in $A$. glacialis culture water was notably higher after the 7th day, when the algae started to die (Fig. 5A). Bacteria growing in experiments with A. glacialis batch-culture filtrate collected during the growth phase (Day 7, Fig. 5A) had a growth lag-phase of 1 full day (Fig. 5B). However, bacteria growing in experiments with filtrate from the diatom death phase (Day 14, Fig. 5A) were characterized by the absence of any discernible bacterial lag phase (Fig. 5C). As in the previous experiment, we found no bacterial predators (flagellates or ciliates) during routine bacterial counts.

Table 1. Free and attached bacteria abundance in- and outside the Asterionellopsis glacialis patches. Mean values, SD and $t$-test results are shown. ns: not significant

\begin{tabular}{|c|c|c|c|c|}
\hline \multirow{2}{*}{$\begin{array}{l}\text { Date } \\
\text { (dd/mm/yy) }\end{array}$} & \multicolumn{2}{|c|}{ Free bacteria } & \multicolumn{2}{|c|}{ Attached bacteria } \\
\hline & $\begin{array}{c}\text { Inside patch } \\
\left(\times 10^{5} \text { cells ml }^{-1}\right)\end{array}$ & 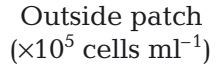 & $\begin{array}{c}\text { Inside patch } \\
\left(\times 10^{5}{\left.\text { cells } \mathrm{ml}^{-1}\right)}^{\text {nat }}\right.\end{array}$ & $\begin{array}{l}\text { Outside patch } \\
\left(\times 10^{5}{\left.\text { cells } \mathrm{ml}^{-1}\right)}^{-}\right.\end{array}$ \\
\hline $27 / 08 / 92$ & 0.53 & 0.49 & $\sim 0$ & $\sim 0$ \\
\hline 03/09/92 & 1.49 & 1.13 & $\sim 0$ & $\sim 0$ \\
\hline 26/09/92 & 0.32 & 0.32 & 0.04 & $\sim 0$ \\
\hline $22 / 10 / 92$ & 0.99 & 1.21 & $\sim 0$ & 0.74 \\
\hline 29/10/92 & 0.46 & 1.42 & 0.6 & 0.56 \\
\hline $10 / 11 / 93$ & 1.43 & 0.71 & 0.32 & 0.11 \\
\hline 19/11/92 & 0.21 & 0.14 & 0.14 & 0.46 \\
\hline 07/04/93 & 0.28 & 0.53 & 2.53 & 0.71 \\
\hline $28 / 05 / 93$ & 0.93 & 0.28 & $\sim 0$ & 1.81 \\
\hline 01/07/93 & 1.74 & 0.42 & $\sim 0$ & 0.53 \\
\hline 03/09/93 & $\sim 0$ & 0.17 & 0.32 & 0.21 \\
\hline Mean & 0.76 & 0.62 & 0.36 & 0.47 \\
\hline SD & 0.59 & 0.44 & 0.75 & 0.53 \\
\hline$t$-test & \multicolumn{2}{|c|}{$\begin{array}{c}\mathrm{p}=0.46 \\
\mathrm{~ns}\end{array}$} & \multicolumn{2}{|c|}{$\begin{array}{c}\mathrm{p}=0.69 \\
\mathrm{~ns}\end{array}$} \\
\hline
\end{tabular}



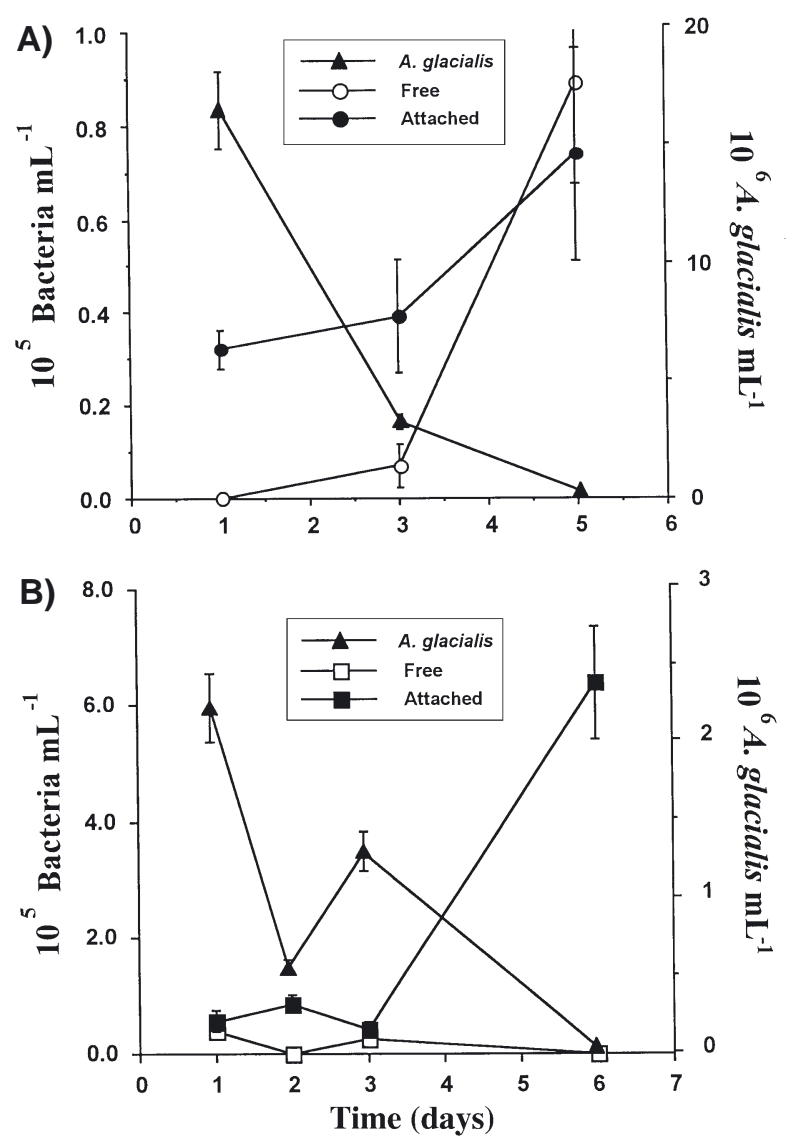

Fig. 3. Free and attached bacterial $\left(10^{5}\right.$ cells $\left.\mathrm{ml}^{-1}\right)$ and Asterionellopsis glacialis abundance between (A) 3 and 9 September 1993 and (B) 12 and 16 February 1996, following peaks of this surf-zone diatom abundance

\section{DISCUSSION}

Despite phenomenal developments in aquatic microbial ecology during the last decades, few studies have been conducted on the surf-zone, probably due to the difficulties of sampling these highly dynamic environments. The first description of the functioning of the microbial food web in dissipative beaches was made by scientists in South Africa. Preliminary estimates based on the surf-zone diatom Anaulus australis and microbial biomass, production and turnover rates indicated that the microbial food web could consume ca. $50 \%$ of surf-zone primary production (McLachlan \& Bate 1985, Brown \& McLachlan 1990). Later, an input-output analysis confirmed the idea that the microbial food web is the major trophic assemblage in the high-energy surf-zone ecosystem (Heymans \& McLachlan 1996). The scenario in which heterotrophic bacteria are major conduits for surf-zone diatom carbon most likely stems from the fact that a large fraction (up to half) of the surf-zone diatom primary production
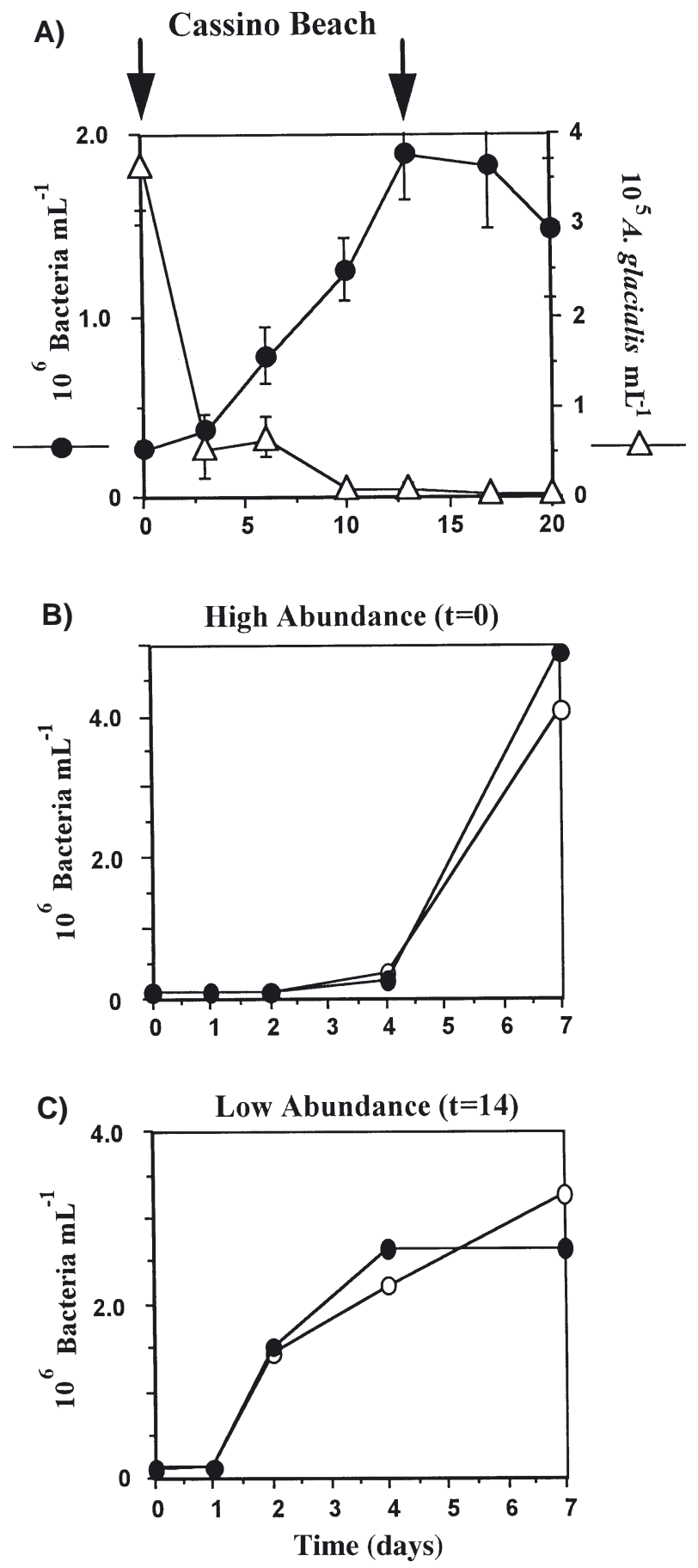

Fig. 4. (A) Asterionellopsis glacialis and heterotrophic bacterial abundance at Cassino Beach between 1 and 22 July 1997. Arrows indicate time of water sampling for laboratory experiments; (B) bacterial abundance (duplicate) in filtered beach water (seawater growth experiments) collected during $A$. glacialis maximum abundance (1 July 1997; $t=0)$; $(\mathrm{C})$ bacterial abundance (duplicate) in filtered beach water (seawater growth experiments) collected when A. glacialis abundance reached lowest levels (15 July 1997; $t=14$ ). Filled and unfilled circles in (B) and (C) represent bacterial abundance from duplicate microcosms 

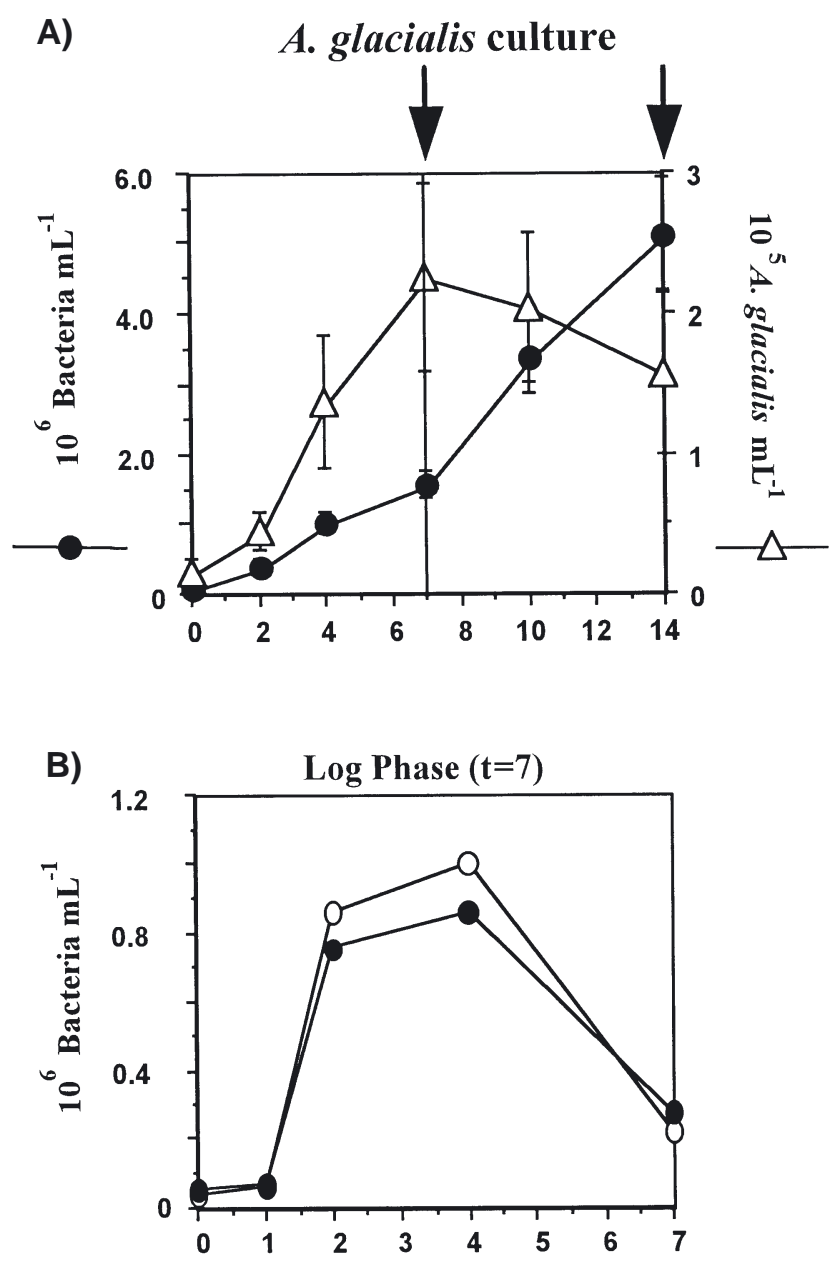

C) Death Phase $(t=14)$

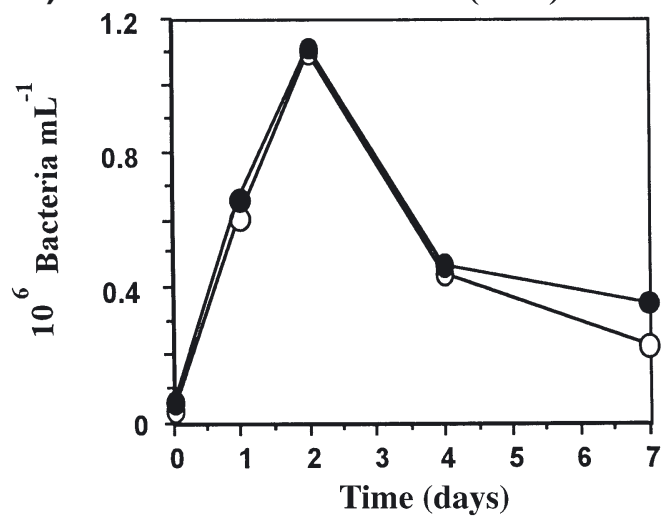

Fig. 5. (A) Asterionellopsis glacialis and heterotrophic bacterial abundance in A. glacialis batch cultures. Arrows indicate times of water sampling for laboratory experiments; (B) bacterial abundance (duplicate) in filtered culture media (culture growth experiments) collected during diatom log-phase $(t=$ 7 ); (C) bacterial abundance (duplicate) in filtered media (culture growth experiments) collected during diatom death phase $(t=14)$. Filled and unfilled circles in (B) and (C) represent bacterial abundance from duplicate microcosms occurs in the dissolved form (Campbell et al. 1985, Brown \& McLachlan 1990, Reynaldi 2000).

It is possible that the high-energy and -light environment of the surf-zone favors elevated rates of extra cellular DOC production of surf-zone diatoms. Talbot \& Bate (1988) suggested that mucus production would be a common feature of all surf-zone diatoms. Cell coating with different adhesive characteristics would allow the diatoms to switch between water column and epibenthic habitats. During the morning these diatoms would adhere to air bubbles and foam, accumulating at the surf-zone. On the other hand, more 'sticky' mucus produced in the afternoon would facilitate the attachment of sand particles to the cells, increasing their density and forcing their sedimentation during this period of the day. After sedimentation, part of the new diatom biomass would be transferred, by rip currents, to sediment beyond the surf-zone. Increasing wave energy would resuspend the diatoms from the epibenthic habitat, giving rise to a new cycle of floating and sedimentation of the cells (Talbot \& Bate 1988, Talbot et al. 1990, Odebrecht et al. 1995, Rörig \& Garcia 2003).

Primary production measurements conducted at Cassino Beach during Asterionellopsis glacialis patches showed that the production of DOM is high ( 0.03 to $3.44 \mathrm{mg} \mathrm{C}^{-1} \mathrm{~h}^{-1}$ ) and may reach $68 \%$ of total (particulate + dissolved) primary production (Reynaldi 2000). Besides this, the levels of total DOC in the waters of Cassino Beach during conditions of $A$. glacialis patches were extremely high (4 to $7 \mathrm{mg} \mathrm{C}^{-1}$; Reynaldi 2000) comparable to those found in highly eutrophic environments (Biddanda et al. 2001).

Based on the assumption that bacteria are the main DOC consumers in any aquatic ecosystem, and considering the fact that a large fraction of surf-zone diatom primary production is in dissolved form, we should expect a significant increase of bacterial biomass at least in the first hours, or days, after the peak of Asterionellopsis glacialis biomass. However, in our study several lines of evidence indicate that bacterial growth at Cassino Beach is not stimulated any further by the large amount of DOC produced by A. glacialis. First, during the yearlong study, bacterial abundance was relatively low, less than that found at the continuous coastal shelf zone (Abreu 1997) and at least 1 order of magnitude lower than that found in the nearby Patos Lagoon estuary (Abreu et al. 1992). It is also notable that the abundance of heterotrophic bacteria in Cassino Beach was several folds lower than those found in freshwater and marine environments at comparable levels of primary production (Cole et al. 1988, Biddanda et al. 2001). Moreover, by the time that $A$. glacialis patches appeared, bacterial number was close to zero (Fig. 2) and there was no significant difference ( $t$-test $\mathrm{p}>0.05$; Table 1 ) between the abundance of 
bacteria outside and inside the diatom patches, where DOC input is supposed to be high.

Second, following the bacterial abundance variation at the beach on a daily basis, it was observed that bacteria take 3 to $4 \mathrm{~d}$ to increase in number after the maximum of Asterionellopsis glacialis abundance (Fig. 3). A similar 'lag' pattern was observed in the bacterial growth experiments at the laboratory, either with the beach water containing a surf-zone diatom bloom (Fig. 4), or A. glacialis batch-culture water (Fig. 5). These series of observations suggested that there was a strong decoupling between heterotrophic bacterial activity and surf-zone diatom production in the Cassino Beach environment. We envisage at least 5 possible reasons for this decoupling, which are: (1) viral infection, (2) bacterial grazing, (3) DOC quality, (4) nutrient competition and (5) antibiotic production.

Regarding the virus action, some studies have demonstrated that bacterial infection by viruses can highly control bacterial production in aquatic environments, influencing biogeochemical and ecological processes in the water (Bratbak et al. 1992, Fuhrman 1999). Viral lyses of bacteria could keep bacterial abundance at low levels as observed in this study. Unfortunately, we have no knowledge of virus abundance/infectivity at Cassino Beach or within our laboratory experiments. Thus, this hypothesis remains to be tested.

The often observed high bacterial production rates with no concomitant bacterial-biomass increase gave rise to the idea that bacterivory is a key mechanism of bacterial losses in aquatic systems (Strom 2000). Bacterivory can be equivalent to bacterial production in oligotrophic systems, while production often exceeds grazing where primary and bacterial production is high. Unpublished data of the Brazilian Long Term Ecological Research monitoring program at Patos Lagoon estuary and adjacent coastal region for the period between 1993 and 2001 show that mean flagellates $\left(9.91 \times 10^{3}\right.$ cells ml ${ }^{-1} \pm 13.63 \times 10^{6}$ cells ml$\left.{ }^{-1}\right)$ and

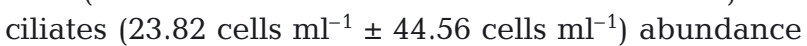
at Cassino Beach are consistently lower than those of the nearby Patos Lagoon estuary (flagellates $=27.63 \times$ $10^{3}$ cells ml ${ }^{-1} \pm 52.23 \times 10^{3}$ cells $\mathrm{ml}^{-1}$ and ciliates $=$ 25.81 cells ml ${ }^{-1} \pm 23.87$ cells ml ${ }^{-1}$ ). Moreover, a recent study on bacterial grazing exerted by flagellates and ciliates conducted in a salinity gradient from the inner estuary to the beach demonstrated that bacterial consumption rates at the beach $\left(0.11\right.$ to $\left.0.19 \mu \mathrm{g} \mathrm{C}^{-1} \mathrm{~h}^{-1}\right)$ are smaller than those measured in estuarine waters (0.33 to $0.60 \mu \mathrm{g} \mathrm{C} \mathrm{l}^{-1} \mathrm{~h}^{-1}$ ) (Hickenbick 2002). We did not measure grazing rates before, during and after the formation of A. glacialis patches. However, the fact that during the laboratory experiments with filtrates from beach water and the Asterionellopsis glacialis batchculture no flagellate or ciliate was recorded, leads us to consider that grazing pressure exerted by the protozooplankton would not be sufficient to prevent bacterial growth at Cassino Beach.

Since Asterionellopsis glacialis particulate and dissolved production at Cassino Beach are relatively high and could potentially sustain increasing levels of bacterial growth, one could speculate that the observed decoupling between A. glacialis and bacteria is related to the quality of DOM exuded by the algae, rather than to its total amount. Bacteria can use DOC of low or high molecular weight (LMW and HMW, respectively), though HMW DOC is utilized at a greater extent (Amon \& Benner 1996). Furthermore, the C:N ratios of DOC produced by phytoplankton of diverse taxonomic groups can be quite different between the pools of HMW DOC (C:N 21) and LMW DOC (C:N 6.0). This could affect the microbial reactivity at different environments, depending on the predominance of HMW or LMW DOC pools, and their sources (Biddanda \& Benner 1997).

Polysaccharides are considered to be the main constituent of HMW DOM found in marine waters and also exuded by phytoplankton (Aluwihare \& Repeta 1999). A cytochemical study of surf-zone diatoms developed by Du Preez \& Campbell (1996) showed that the Asterionellopsis glacialis mucilage coat is made up of a mixture of neutral, acidic and sulphated polysaccharides. It is possible that different proportions of distinct polysaccharides in the DOC exuded by A. glacialis give this microalgae the capacity to bind to foam, or have sand particles attached to them (Rörig \& Garcia 2003), since sticky transparent exopolymer particles (TEP) found in the water are mostly composed of acidic polysaccharides (Passow 2002). If this is the case, bacteria could react differently to exuded DOC produced at different periods of the day.

It is noteworthy that the production of large amounts of TEP during a diatom bloom flocculation off Santa Barbara (USA) was not followed by an increase in bacterial number (Passow \& Alldredge 1994), similar to the observations in the present study. Sherr \& Sherr (1996) have also observed that diatoms may produce HMW organic compounds that may not be immediately used by bacteria. It is likely that mucus-rich exudates from surf-zone diatoms are not a good growth substrate for heterotrophic bacterioplankton.

The concentration of dissolved inorganic nutrients (ammonium, nitrite + nitrate and phosphate) at Cassino Beach is quite low in comparison to the estuarine water of the Patos Lagoon, but it is far from being considered an oligotrophic system. An increase in nutrient availability in the coastal region occurs after strong rainfalls and increasing freshwater outflow from 
the Patos Lagoon (Ciotti et al. 1995). However, higher nitrogenous nutrients concentration at Cassino Beach is normally observed in water of high salinity, suggesting that the input of this nutrient results from the resuspension of the near-shore sediments due to the action of onshore southerly winds (Odebrecht et al. 1995). Phosphate concentration, on the other hand, is quite high and stable during most of the year (Odebrecht et al. 1995, Rörig \& Garcia 2003)

One of the strategies used by cells to survive in a low-nutrient environment is to grow more slowly. However, considering the nutrient levels at Cassino Beach, there is no reason to conclude that bacterial growth would be limited by the lack of dissolved inorganic nutrients (especially $\mathrm{N}$ and $\mathrm{P}$ ). On the other hand, the production of antibiotic substances by the algae could hinder bacterial growth, as observed here, and favor Asterionellopsis glacialis in a direct competition with bacteria for dissolved inorganic nutrients. Bioassays (nutrient addition studies) conducted at the Patos Lagoon estuary showed that carbon is not a limiting factor, while nitrogen and phosphorus stimulate the bacterial growth in this ecosystem (Cesar \& Abreu 2001). Thus, it is likely that bacteria at Cassino Beach have similar dissolved inorganic nutrient requirements, since both water bodies are closely connected.

Aubert et al. (1970) were the first to chemically characterize an antibiotic synthesized by Asterionellopsis glacialis (at that time Asterionella japonica). The antibiotic is a nucleoside (molecular weight $=245$ ) made up of a pyrimidinic base and a pentose sugar, probably arabinose. The structure of this nucleoside is analogous to thymidine, but is different in that it has an antimitotic property. Antibiotic action exerted by $A$. glacialis was previously reported in studies with Staphylococcus aureus (Aubert et al. 1970) and Vibrio spp. (Riquelme et al. 1989); however, this same algae stimulated the growth of bacteria from the genera Pseudomonas (Riquelme et al. 1989). Such results point out the fact that the antibiotic produced by A. glacialis is not one of a broad spectrum.

One consequence of the diatom-bacteria decoupling at Cassino Beach is the accumulation of surplus DOC in this environment. This organic matter will not reach higher trophic levels through the microbial food web. Besides this, the suppression of heterotrophic bacteria by Asterionellopsis glacialis will enable a greater transfer of diatom carbon to metazoan consumers in the surf-zone, since dead diatoms will not be immediately decomposed by bacteria. Further, excess surfzone diatom production may be exported to the coastal ocean, where it may fuel heterotrophic secondary production. Alternatively, due to the high energy of the surf-zone ecosystem, bubble production and the 'sticky' characteristic of mucus produced by $A$. glacialis, particulate organic matter aggregates could be formed and further consumed by benthic and pelagic filter feeders and other omnivorous organisms in the nearshore ecosystem, as observed in other studies (Larson \& Shanks 1996).

It is noteworthy that Cassino Beach supports a high biomass of benthic filter-feeding organisms such as the crustacean Emerita brasiliensis and the bivalves Mesodesma mactroides and Donax hanleyanus. Accumulated annual production at Cassino Beach of these organisms reaches 238.5, 185.3 and $13.6 \mathrm{~g} \mathrm{~m}^{-2}$, respectively (Gianuca 1997). They supply abundant food resources for a variety of secondary consumers like fish and shore birds. Garcia \& Gianuca (1997) observed that, during summer, $90 \%$ of the stomach content of dominant resident and migratory birds at Cassino Beach is composed of the filter feeders M. mactroides, $D$. hanleyanus and E. brasiliensis. It is likely that surplus organic matter produced by Asterionellopsis glacialis in particulate and also dissolved form, which is not consumed by bacteria, is channeled to the benthic populations, generating high secondary production.

The food-web dynamics prevailing in Cassino Beach (Brazil) during blooms of the surf-zone diatom have parallels to events occurring in Newfoundland waters (Canada), where the suppression of bacteria due to very low temperatures in early springtime presumably results in enhanced transfer of phytoplankton production to benthic fisheries (Pomeroy \& Deibel 1986). Unlike Newfoundland waters, however, at Cassino Beach the temperatures rarely fall below $10^{\circ} \mathrm{C}$, and the bacteria were decoupled from the surf-zone diatom without any systematic bias towards the winter or summer seasons (Fig. 2). Studies have demonstrated that, even at low temperatures, bacterial growth and respiration could be raised by increasing the organic substrate concentration (Pomeroy \& Wiebe 2001). However, bacterial abundance as well as activity at Cassino Beach did not increase, despite the high rate of DOC input from Asterionellopsis glacialis and the high concentrations of DOC prevailing in the water, suggesting that another controlling mechanism besides temperature, such as DOC quality (Pomeroy \& Deibel 1986, Sherr \& Sherr 1996), viral lyses (Fuhrman 1999), bacterivory (Strom 2000), or production of antibiotic substances (Aubert et al. 1970, Requelme et al. 1989), can also cause a decoupling between diatoms and bacteria.

Preliminary results of this study demonstrate that the microbial ecology of surf-zone environments is more complex than previously imagined. The input of extra energy by wind and waves that benefit the surf-zone diatom Asterionellopsis glacialis production do not fuel bacterial growth at the same time. Future studies should consider the characteristic decoupling between 
A. glacialis and bacteria interaction and characterize how much of the produced DOC is actually utilized by the microbial food web in the long term. Studies should also explore the consequences of such temporal suppression of the microbial loop in surf-zone-diatomdominated ecosystems to the carbon dynamics of the nearshore food webs.

Acknowledgements. Valnei Rodrigues provided technical assistance in the field and laboratory. Environmental data for Cassino Beach during 1992 to 1993 was gathered as part of the MSc thesis work by L.R.R. (Rorig 1997). P.C.A. and C.O. received financial support from the Conselho Nacional de Desenvolvimento Científico e Tecnológico-CNPq, Brazil. B.B. was supported by CNPq, Brazil, on a visiting scientist program (1997-98). We thank 2 anonymous referees for their comments on a previous version of this manuscript.

\section{LITERATURE CITED}

Abreu PC (1997) Coastal and marine environments and their biota-bacterioplankton. In: Seeliger U, Odebrecht C, Castello JP (eds) Subtropical convergence environments: the coast and sea in the southwestern Atlantic. SpringerVerlag, Berlin, p 104-105

Abreu PC, Biddanda B, Odebrecht C (1992) Bacterial dynamics of the Patos Lagoon estuary, Southern Brazil $\left(32^{\circ} \mathrm{S}\right.$, $52^{\circ} \mathrm{W}$ ): relationship with phytoplankton production and suspended material. Estuar Coast Shelf Sci 35:621-635

Aluwihare LI, Repeta DJ (1999) A comparison of the chemical characteristics of the oceanic DOM and extracellular DOM produced by marine algae. Mar Ecol Prog Ser 186: 105-117

Ammerman JW, Fuhrman JA, Hagstrom A, Azam F (1984) Bacterioplankton growth in seawater. I. Growth kinetics and cellular characteristics in sea water cultures. Mar Ecol Prog Ser 18:31-39

Amon RMW, Bener R (1996) Bacterial utilization of different size classes of dissolved organic matter. Limnol Oceanogr 41:41-51

Aubert M, Pesando D, Gauthier M (1970) Phenomenes d'antibiosi d'origine phytoplanctonique en milieu marin. Rev Int Océanogr Méd 18-19:69-76

Biddanda B, Benner R (1997) Carbon, nitrogen, and carbohydrate fluxes during the production of particulate and dissolved organic matter by marine phytoplankton. Limnol Oceanogr 42:506-518

Biddanda BA, Ogdahl M, Cotner JB (2001) Dominance of bacterial metabolism in oligotrophic relative to eutrophic waters. Limnol Oceanogr 46(1):730-739

Bratbak G, Heldal M, Thingstad TF, Riemann B, Haslund OH (1992) Incorporation of viruses into the budget of microbial C-transfer: a first approach. Mar Ecol Prog Ser 83:273-280

Brown AC, McLachlan A (1990) Ecology of sandy shores. Elsevier, Amsterdam

Campbell EE, Fock HP, Bate GC (1985) Exudation of recently fixed photosynthetic products from surf zone phytoplankton of the Sundays River beach. Bot Mar 28:399-405

Cesar DE, Abreu PC (2001) Ecology of aquatic microorganisms in Southern Brazil: state of art. In: Faria BM, Farjalla VF, Esteves FA (eds) Aquatic microbial ecology in Brazil. Oecol Brasil, EDUFRJ, Rio de Janeiro, p 153-172

Ciotti AM, Odebrecht C, Fillmann G, Möller O Jr (1995) Freshwater outflow and subtropical convergence influ- ence on phytoplankton biomass on the southern Brazilian continental shelf. Cont Shelf Res 14:1737-1756

Cole JJ, Findlay S, Pace ML (1988) Bacterial production in fresh- and saltwater ecosystems: a cross system overview. Mar Ecol Prog Ser 43:1-10

Du Preez DR, Campbell EE (1996) Cell coatings of surf diatoms. Rev Chil Hist Nat 69:539-544

Fuhrman JA (1999) Marine viruses and their biogeochemical and ecological effects. Nature 399:541-548

Garcia V, Gianuca N (1997) The beach and the surf zone. In: Seeliger U, Odebrecht C, Castello JP (eds) Subtropical convergence environments: the coast and sea in the southwestern Atlantic. Springer-Verlag, Berlin

Gianuca N (1997) Coastal and marine environments and their biota-benthic beach invertebrates. In: Seeliger U, Odebrecht C, Castello JP (eds) Subtropical convergence environments: the coast and sea in the southwestern Atlantic. Springer-Verlag, Berlin, p 102-104

Guillard NM, Ryther JH (1962) Studies of marine diatoms. I. Cyclotella nana Husted and Detonula confervacea (Cleve) Gran. Can J Microbiol 8:229-239

Heymans J, McLachlan A (1996) Carbon budget and network analysis of a high-energy beach/surf-zone ecosystem. Estuar Coast Shelf Sci 43:485-505

Hickenbick GR (2002) Predação de bactérias pelo protozooplâncton em um gradiente de salinidade e seu efeito no balanço de massa bacteriano. MSc thesis, Federal University of Rio Grande

Hobbie JE, Daley RJ, Jasper S (1977) Use of Nuclepore filters for counting bacteria by fluorescence microscopy. Appl Environ Microbiol 3:1225-1228

Larson ET, Shanks L (1996) Consumption of marine snow by two species of juvenile mullet and its contribution to their growth. Mar Ecol Prog Ser 130:19-28

McLachlan A, Bate G (1985) Carbon budget for a high energy surf zone. Vie Milieu 34:67-77

Nishino SF (1986) Direct acridine orange counting of bacteria preserved with acidified lugol iodine. Appl Environ Microbiol 52:602-604

Odebrecht C, Segatto AZ, Freitas CA (1995) Surf-zone chlorophyll a variability at Cassino Beach, southern Brazil. Estuar Coast Shelf Sci 41:81-90

Passow U (2002) Transparent exopolymer particles (TEP) in aquatic environments. Prog Oceanogr 55:287-333

Passow U, Alldredge AL (1994) Distribution, size and bacterial colonization of transparent exopolymer particles (TEP) in the ocean. Mar Ecol Prog Ser 113:185-198

Pomeroy L, Deibel D (1986) Temperature regulations of bacterial activity during the spring bloom in Newfoundland coastal waters. Science 233:359-361

Pomeroy L, Wiebe WJ (2001) Temperature and substrates as interactive limiting factors for marine heterotrophic bacteria. Aquat Microb Ecol 23:187-204

Reynaldi S (2000) Efeito da diatomácea de zona de arrebentação Asterionellopsis glacialis (Castracane) Round, sobre o crescimento bacteriano na Praia do Cassino, RS-Brasil. MSc thesis, Federal University of Rio Grande

Riquelme CE, Fukami K, Ishida Y (1989) Growth response of bacteria to extracellular products of bloom algae. Nippon Suisan Gakkaishi 55:349-355

Rörig LR (1997) Acumulações da diatomácea Asterionellopsis glacialis e sua relação com variáveis ambientais na Praia do Cassini, Rio Grande. MSc thesis, Federal University of Rio Grande

Rörig LR, Garcia VMT (2003) Accumulations of the surf-zone diatom Asterionellopsis glacialis (CASTRACANE) ROUND in Cassino Beach, Southern Brazil, and its rela- 
tionship with environmental factors. J Coast Res SI 35: 167-177

Sherr EB, Sherr BF (1996) Temporal offset in oceanic production and respiration processes implied by seasonal changes in atmospheric oxygen: the role of heterotrophic microbes. Aquat Microb Ecol 11:91-100

Short AD, Wright LD (1983) Physical variability of sandy beaches. In: McLachlan A, Erasmus T (eds) Sand beaches as ecosystems. W Junk, The Hague, p 133-144

Sokal RR, Rohlf FJ (1969) Biometry: the principles and practice of statistics in biological research. WH Freeman, San Francisco

Strickland J, Parsons T (1972) A practical handbook of seawater analysis. Fisheries Research Board Canada, Ottawa

Editorial responsibility: David Karl,

Honolulu, Hawaii, USA
Strom SL (2000) Bacterivory: interactions between bacteria and their grazers. In: Kirchman DL (ed) Microbial ecology of the oceans. Wiley-Liss, New York, p 351-386

Talbot M, Bate G (1988) The use of false buoyancies by the surf diatom Anaulus birostratus in the formation and decay of cell patches. Estuar Coast Shelf Sci 26:155-167

Talbot M, Bate G, Campbell E (1990) A review of the ecology of surf-zone diatoms, with special reference to Anaulus australis. Oceanogr Mar Biol Annu Rev 28:155-175

Throndsen J (1978) Preservation and storage. In: Sournia A (ed) Phytoplankton manual. UNESCO, Paris, 69-74

Utermöhl H (1958) Zur Vervollkommnung der quantitativen Phytoplankton Methodik. Mitt Int Ver Theor Angew Limnol 9:1-38

Submitted: August 16, 2002; Accepted: April 17, 2003

Proofs received from author(s): July 2, 2003 